\title{
UN EJEMPLO DE LA INFLUENCIA DE LA PINTURA FRANCESA EN LA PINTURA ANDALUZA DEL XIX
}

\author{
por Manuel Piñanes García-Olias
}

El estudio de la influencia de la pintura francesa decimonónica en la andaluza del mismo período ha sido poco frecuente. Sin embargo, la llegada a Andalucía de pintores franceses, algunos de ellos atraídos por la protección del Duque de Montpensier, no fue rara (P. Blanchard, A. Dauzats, A. Dehodencq). El mismo Duque de Montpensier poseía en su valiosa colección una selección muy notable de la pintura francesa del siglo XIX.

Por todo esto es posible que a medida que se profundice en el estudio de nuestra pintura del siglo pasado podamos corroborar probables influencias y préstamos de la pintura francesa.

Un caso concreto es el cuadro del pintor gaditano Juan José de Urmeneta (1801-1883) titulado "Capuchinos en el coro" conservado en el Museo de Bellas Artes de Cádiz. Se trata de una copia de un cuadro del mismo asunto original del pintor francés nacido en Axi en Provence François Marius Granet (1775-1845). Granet fue, por breve tiempo, discípulo de David y en 1802 se trasladó a Roma donde se hizo una reputación pintando cuadros de interiores de iglesias y conventos. Gracias a una de estas pinturas, titulada "Coro de los Capuchinos de la plaza Barberini" obtuvo un resonante éxito y la consolidación de su fama como pintor cuando se presentó en el Salón de 1819. El éxito fue tal que ante el requerimiento y la exigencia de personalidades ilustres y principales de poseer el famoso cuadro tuvo que hacer dieciséis réplicas del mismo. Sin embargo, introdujo en cada una de ellas ligeras variantes singularizadoras. A partir de aquí la carrera de Granet fue recompensada por la Legión de Honor y sus cargos en los museos franceses ${ }^{1}$.

1. Benezit, E.: Dictionnaire des peintres, sculpteurs, dessinateurs et graveurs, Tomo IV, 1966. 
No sabemos cómo Urmeneta llegó a conocer esta composición y repetirla en un cuadro suyo, aunque probablemente se debiera a la propia fama del cuadro y a sus numerosas versiones, a lo que pudo añadirse una difusión a través de grabados o estampas por toda Europa. Es posible que Urmeneta la conociera ya que era profesor de la Academia de Cádiz ${ }^{2}$. Por otra parte, la afinidad del asunto con los temas costumbristas y de género que practicaban abundantemente los pintores andaluces a lo largo del siglo XIX explicaría esta preferencia del pintor gaditano por el Coro de los Capuchinos.

Por otro lado, sabemos que en la colección del Duque de Montpensier figuraban dos cuadros de F.M. Granet catalogados con los números 344 y 354 que representaban respectivamente a "El despensero de un colegio" y a "Un fraile trinitario"3. Esta colección que, como ya hemos indicado contenía otras obras de pintores galos además de las ya mencionadas, pudo ser un importante vehículo de conocimiento de la pintura francesa de la época.

2. Ossorio y Bernard, M.: Galería Biográfica de artistas españoles del siglo XIX, Madrid, 1975.

3. Catálogo de los cuadros y esculturas pertenecientes a la galería de SS.AA.RR. los serenísimos Señores Infantes de España Duques de Montpensier, Sevilla, 1886. 


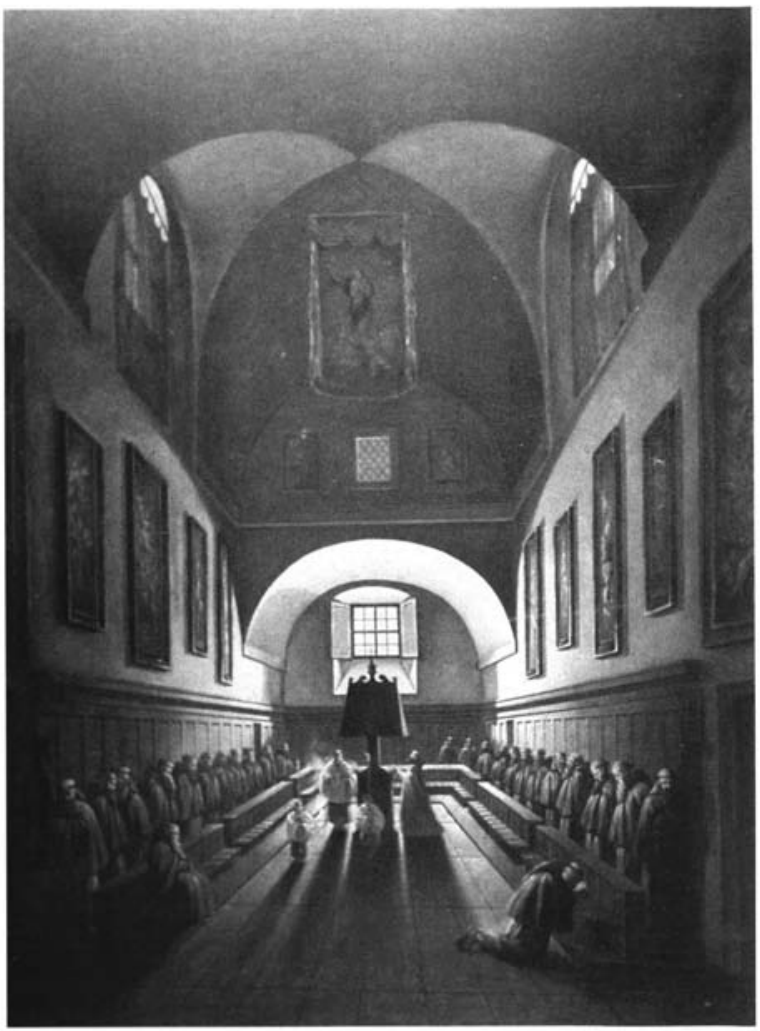

Coro de Capuchinos.

J. J. Urmeneta 


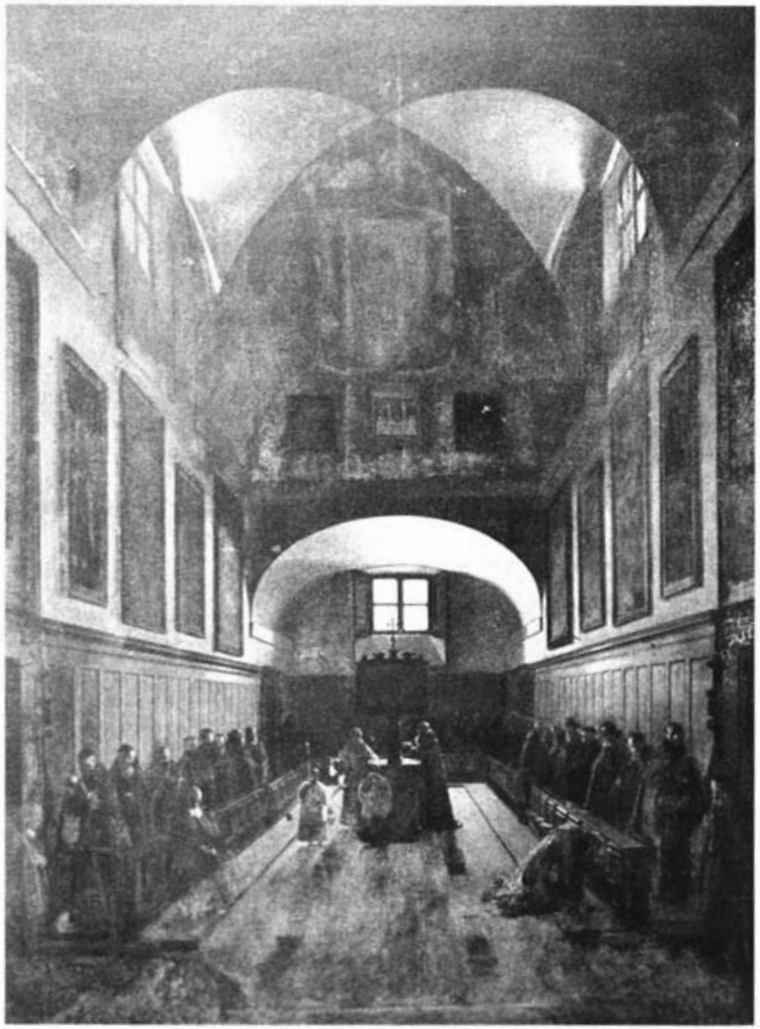

Coro de Capuchines de Roma

F. M. Granct. 1817. 